\title{
PENGARUH PRODUKTIVITAS TERHADAP NERACA TRANSAKSI BERJALAN DI NEGARA ASEAN TAHUN 1995-2015
}

\section{The effect of Productivity on Current Account in ASEAN countries within 1995-2015}

\author{
Yulia Sasmiranti ${ }^{1}$; Abdul Hadi Ilman ${ }^{1}$; Muhammad Nurjihadi ${ }^{1}$ \\ ${ }^{1}$ Program Studi Ekonomi Pembangunan, Fakultas Ekonomi dan Bisnis, Universitas Teknologi Sumbawa
}

*) E-mail : yuliasasmiranti@gmail.com

\begin{abstract}
The paper investigates the effect of Productivity and Investment on Current Account in ASEAN Countries from 1996 to 2015. Where the dependent variable is absolute change in current account and the independent variables are investment in the previous years which is proxy form gross capital formation and change in inventories, the absolute change in productivity percentage, and the current account itself in the previous years. The data was analyzed using quantitative analysis with pooled data regression model. There are seven ASEAN countries was taken as the research samples, Such as: Cambodia, Indonesia, Malaysia, Philippines, Singapore, Thailand, and Vietnam. Based on the Hausman test and Lagrange Multiplier (LM) test, the best estimation model for this research is Random effect model. The results of this paper shows that productivity have negative effect on current account significantly with Probability $0.0471<0.05$ (95\% confidence level), it's causes of the ASEAN productivity effect on the current account through economic growth. While investment have negative effect also, even not significantly with probability $0.6655>0.05$ because the investement rate in ASEAN countries was not higher than the saving rate except Cambodia.
\end{abstract}

Key words: Productivity, investment, and current account.

\begin{abstract}
ABSTRAK
Skripsi ini bertujuan untuk menganalisis pengaruh produktivitas dan terhadap neraca transaksi berjalan di negara ASEAN tahun 19962015. Dimana variabel dependen dalam penilitian ini adalah perubahan absolut pada transaksi berjalan, dengan variabel independen sebagai berikut: Investasi pada tahun sebelumnya yang diproksi dari gross capital formatioan dan change in inventories, perubahan absolut pada persentase produktivitas, dan transaksi berjalan itu sendiri pada tahun sebelumnya. Analisis data menggunakan analisis kuantitatif dengan model regresi data panel, ada tujuh negara ASEAN yang diambil sebagai sampel penelitian, antara lain: Cambodia, Indonesia, Malaysia, Philippines, Singapore, Thailand, dan Vietnam. Berdasarkan Uji Hausman dan Uji Lagrange Multiplier (LM) model estimasi terbaik yang dipilih dalam penelitian adalah Random effect model. Hasil penelitian dari model Random effect memperlihatkan bahwa produktivitas berpengaruh negatif dan signifikan terhadap transaksi berjalan, dengan tingkat probabilitas $0.0471<0.05$ (tingkat kepercayaan 95\%), disebabkan karena produktivitas negara ASEAN dari tahun 1996-2015 mempengaruhi transaksi berjalan secara tidak langsung melalui pertumbuhan ekonomi. Sedangkan investasi yang ditetapkan dari jumlah gross fix capital formastion dan change in stock (inventories) memiliki pengaruh yang negatif terhadap perubahan absolut transaksi berjalan tetapi tidak signifikan, dimana tingkat probabilitas $0.6655>0.05$ yang disebabkan karena tingkat investasi negara ASEAN sejak tahun 1996-2015 tidak lebih besar dibandingkan dengan tingkat saving (tabungan) dari masing-masing negara kecuali Cambodia.
\end{abstract}

Kata kunci: Produktivitas, investasi, dan transaksi berjalan.

\section{Pendahuluan}

Sistem perekonomian dunia di era globalisasi ini pada umumnya menganut sistem perekonomian terbuka. Keterbukaan perekonomian (openness) memiliki dampak pada neraca pembayaran yang berkaitan dengan arus perdagangan dan lalu lintas modal. Salah satu struktur yang terdapat di dalam neraca pembayaran disebut dengan neraca transaksi berjalan atau Current Account.

Neraca transaksi berjalan dapat dikatakan sebagai patokan penawaran ekspor suatu negara yang telah dikurangi dengan permintaan impornya. Keseimbangan neraca transaksi berjalan merupakan kunci indikator ekonomi makro untuk perekonomian terbuka. Transaksi berjalan yang sehat dan berkelanjutan muncul ketika suatu negara menghasilkan pendapatan ekspor yang cukup untuk membayar impornya atau tidak terlalu bergantung dengan arus masuk mata uang

asing, biasanya dalam bentuk investasi atau hutang eksternal untuk menyelesaikan tagihan impor (Khadaroo, 2012).

Jika neraca transaksi berjalan bertanda negatif (-) maka artinya impor suatu negara lebih tinggi dari ekspor, sehingga mengalami defisit atau current account deficit dan apabila bertanda positif (+) artinya ekspor lebih besar dari pada impor, sehingga mengalami surplus atau current account surplus, Dengan begitu tingkat ekspor berperan penting dalam defisit maupun surplus neraca transaksi berjalan.

Salah satu cara untuk mingkatkan ekspor adalah dengan miningkatkan produktivitas. Produktivitas pada umumnya diartikan sebagai rasio antara input dan output, yaitu seberapa banyak output yang dapat dihasilkan dari input yang digunakan. Produktivitas merupakan salah satu 
indikator bangsa untuk mencapai tingkat pertumbuhan ekonomi yang tinggi. (Lieberman, 2008).

Berdasarkan data yang dirilis Asian Productivity Organization (APO) tahun 2017 pada grafik 1.1 , indeks produktivitas negara ASEAN selama lima tahun terakhir sejak 2011 hingga 2015 mengalami peningkatan setiap tahunnya, terutama negara Lao PDR yang rata-rata pertahun meningkat hingga $7,45 \%$. Jika dilihat dari indeks produktivitas pada grafik 1.1, tingkat produktifitas kerja Indonesia berada di atas Malaysia, Philippines dan Singapore.

Artinya produktivitas kerja Indonesia lebih besar dibandingkan tiga negara tersebut. Namun jika kita melihat data neraca transaksi berjalan pada grafik 1.2, neraca ransaksi berjalan Indonesia justru mengalami defisit selama beberapa tahun terakhir dibandingkan dengan Malaysia, Philippines dan Singapore yang selalu mengalami surplus neraca transaksi berjalan pada tahun yang sama.

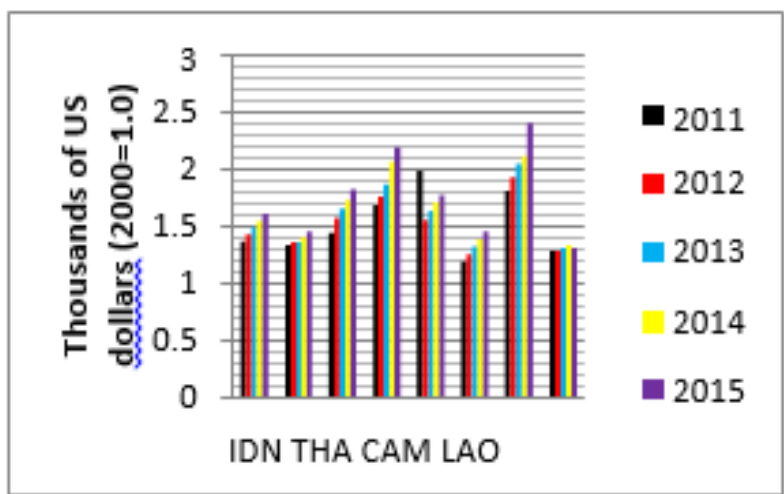

Grafik 1. Indeks Labor Productivity ( based on Hour Worked) tahun 2011-2015

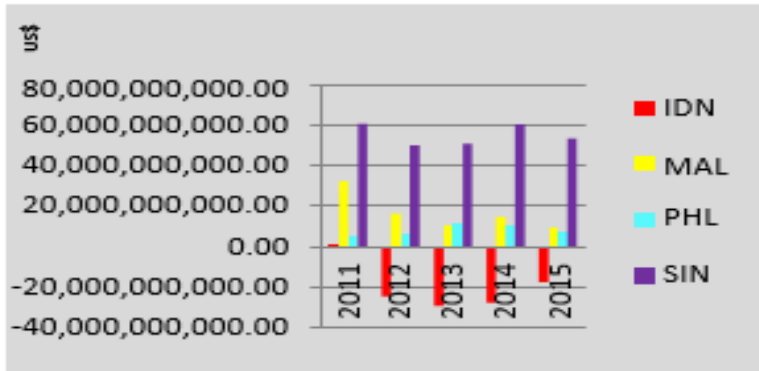

Grafik 2. Neraca transaksi berjalan (BoP, current US\$) tahun 20112015

Uraian tersebut bertentangan dengan hasil penelitian Sugiartiningsih (2013) yang mengungkapkan bahwa pengaruh produktivitas kerja terhadap ekspor bersifat positif, setiap peningkatan pada produktivitas kerja akan diikuti oleh peningkatan ekspor. Kemudian ekspor berkontribusi secara positif terhadap neraca transaksi berjalan. Namun Newman (2012) mengemukakan dalam penelitiannya bahwa bukti tentang sifat hubungan antara ekspor dan produktivitas tidak meyakinkan, terutama untuk negara berkembang. Sementara Indonesia merupakan negara berkembang, pun negara ASEAN didominansi oleh negara berkembang.

Hasil penelitian Newman (2012) di perkuat oleh Gracia (2001) yang menemukan bahwa pengaruh peningkatan produktivitas di satu negara terhadap transaksi berjalan bersifat rancu. Di satu sisi, meningkatkan pendapatan negara yang kemudian dipinjamkan ke seluruh dunia untuk kelancaran konsumsi dari waktu ke waktu. Dan di sisi lain, mendorong negara untuk meminjam dari seluruh dunia untuk membiayai investasi. Pengaruh yang pertama mendorong neraca transaksi berjalan ke arah surplus sementara pengaruh yang kedua kearah defisit.

Glick and Rogoff (1995) menemukan bahwa investasi secara konsisten dan signifikan merespon positif productivity shock spesifik negara (domestik) dan produktivitas global. Sementara neraca transaksi berjalan merespon secara negatif dan signifikan terhadap produktivitas spesifik negara, dan tidak ada respon apapun terhadap productivity shock global.

Sederhanyanya neraca transaksi berjalan secara negatif dipengaruhi oleh produktivitas domestik. Model tersebut memprediksikan bahwa productivity shock permanen secara signifikan akan meningkatkan investasi yang dibiayai melalui pinjaman internasional, yang akhirnya membimbing transaksi berjalan kearah pemerosotan yang cukup besar.

Valderrama (2007) mengemukakan bahwa defisit transaksi berjalan Amerika Serikat telah berkembang pesat, terutama sejak tahun 1996, pada saat yang sama, tingkat pertumbuhan produktivitas tenaga kerja Amerika Serikat hampir dua kali lipat. Pertumbuhan produktivitas ini dapat berpotensi menjadi bagian dari peningkatan transaksi berjalan melalui dampaknya terhadap tabungan dan investasi. Jika akselerasi atau percepatan pertumbuhan produktivitas bersifat permanen. Ketika pendapatan meningkat, tingkat tabungan juga akan meningkat. Hal ini terjadi karena suatu individu akan mengambil keuntungan melalui peningkatan pendapatan mereka dengan meminjam sejak awal dan akhirnya akan mulai membayar kembali pinjaman mereka tadi, yang akhirnya hal tersebut cenderung akan membawa transaksi berjalan ke arah surplus.

Perbedaan antara berbagai pendapat dan latar belakang tersebut, sehingga peneliti ingin menganalisis pengaruh produktivitas dan investasi terhadap neraca transaksi berjalan di negara ASEAN tahun 1996-2015. Berdasarkan uraian latar belakang tersebut maka tujuan dari penelitian ini adalah Untuk menganalisis pengaruh produktivitas dan investasi terhadap neraca transaksi berjalan di beberapa negara ASEAN tahun 1995-2015.

\section{Metode Penelitian}

Dalam penelitian ini peneliti menggunakan metode penelitian kuantitatif. Data yang digunakan dalam penelitian ini antara lain perubahan Absolut neraca transaksi berjalan (Current Account) sebagai variabel dependen. Data perubahan Absolut persentase produktivitas (Total Factor Productivity), yang diperoleh dari nilai persentase produktivitas pada tahun $\mathrm{t}$ dikurangi dengan nilai persentase produktivitas pada tahun sebelumnya (Ait - Ait-1). Investasi yang ditetapkan dari jumlah gross fix capital formastion dan change in stock (inventories) negara ASEAN tahun 1996-2015, dimana investasi yang digunakan dalam regresi model adalah investasi pada tahun sebelumnya $\left(\mathrm{I}_{\mathrm{it}-1}\right)$. Transaksi berjalan pada tahun sebelumnya (CAit-1). Sumber data dalam penelitian ini adalah data sekunder yang diperoleh dari hasil publikasi beberapa lembaga atau institusi, yakni The World Bank, Asian Productivity Organization (APO), dan 
International Monetary Fund (IMF), International Financial Statistics (IFS).

\section{Model Regresi Data Panel}

Dalam menganalisis seberapa besar pengaruh produktivitas terhadap transaksi berjalan (Currrent Account) dalam penelitian ini, penulis menggunakan fungsi persamaan transaksi berjalan berdasarkan national accounts (Terra, 2015:70):

$$
C A_{t}=Y_{t}+r B_{1}-C_{t}
$$

Dimana CA adalah transaksi berjalan, Yt adalah sumbangan ekonomi sesuai denga GDP, Bt adalah Net International Investment Position (NIIP), dan rBt adalah net investement income negara.

Berdasarkan hasil estimasi Glick dan Rogoff (1995) persamaan transaksi berjalan yang digunakan merupakan kombinasi dari persamaan investasi dan konsumsi sebagai berikut:

$$
\begin{gathered}
\Delta I_{t}=\left(\beta_{1}-1\right) I_{t-1}+\beta_{2} \Delta A_{t}^{c} \\
\text { dan } \\
\Delta C_{1}=\left\{\frac{\beta_{2}\left[\left(x_{1}-1\right)(r-1)+x_{k}\right]}{r-\beta_{1}}+\alpha_{A}\right\} \Delta A_{t}^{c}
\end{gathered}
$$

Dimana $\Delta \mathrm{I}$ adalah prubahan absolut pada investasi, $\Delta \mathrm{Ac}$ adalah perubahan absolut pada produktivitas suatu negara, $\Delta \mathrm{C}$ adalah perubahan absolut pada konsumsi. Sehingga hasil yang didapat dari kombinasi kedua persamaan tersebut adalah:

$$
\Delta C A_{t}=\gamma_{1} I_{t-1}+\gamma_{2} \Delta A_{t}^{c}+(r-1) C A_{t-1},
$$

Dimana Perubahan absolut pada transaksi berjalan $(\Delta \mathrm{CA})$ adalah effek dari nilai lag pada transaksi berjalan itu sendiri, begitu pula variabel lainnya. Kemudian dari persamaan tersebut diperoleh model regresi yang akan diteliti oleh penulis dengan alternatif model sebagai berikut:

$$
\Delta C A_{i t}=\beta_{0}+\beta_{1} I_{i t-1}+\beta_{2} \Delta A_{i t}+\beta_{3} C A_{i t-1}+\varepsilon_{i t}
$$

Dimana:

$$
\begin{array}{ll}
\Delta \mathrm{CA} & =\text { Perubahan absolut transaksi berjalan } \\
\mathrm{I}_{\mathrm{it}-1} & =\text { Investasi pada tahun sebelumnya } \\
\Delta \mathrm{A} & =\text { Perubahan absolut persentase produktivitas } \\
C A_{i t-1} & =\text { Transaksi berjalan pada tahun sebelumnya } \\
\beta_{0} & =\text { Konstanta } \\
\beta_{1}, \beta_{2}, \beta_{3} & =\text { Koefisien regresi masing-masing variabel } \\
\varepsilon_{1 \mathrm{it}} & =\text { error term } \\
i & =\text { cross } \text {-section } \text { data panel } \\
t & =\text { time series }
\end{array}
$$

\section{Pemilihan Model}

Estimasi model regresi yang digunakan untuk data panel menurut Gujarati (2004:640) adalah sebagai berikut:

The pooled Least Square (Common Effect), Pendekatan ini menggunakan metode kuadrat terkecil biasa sehingga sering disebut sebagai pendekatan yang paling sederhana untuk data panel. Diasumsikan bahwa komponen error dalam Ordinary Least Square (OLS) dapat dilakukan dua proses estimasi, yakni pertama dengan cara terpisah antara setiap unit crosssection atau time series dan yang kedua dengan cara menggabungkan cross-section dan time series.

The Fixed Effects Approach (Pendekatan Efek Tetap), Diasumsikan bahwa slope coefficients konstan dari waktu ke waktu tetapi intercept antar individu berbeda. Dengan intercept antar individu yang berbeda model ini menggunakan teknik variabel dummy untuk mengestimasi data panel guna membedakan intercept-nya, sehingga model ini juga disebut dengan model regresi Least-Squares Dummy Variable (LSDV). Dengan konsekuensi hilangnya jumlah derajat kebebasan.

The Random Effect Approach (Pendekatan Efek Acak), Pada umumnya model ini disebut juga Error Components Model (ECM) atau Random Effects Model (REM). Dengan asumsi bahwa adanya variabel acak. Perbedaan intercept antar individu terccermin dalam error term. Komponen error antar individu tidak berkorelasi satu sama lain dan tidak autokorelasi di kedua unit cross- section dan time series.

Untuk memilih model panel yang akan digunakan dalam penelitian data panel adalah dengan meggunakan tiga tahapan sebagai berikut dalam melakukan uji formal (Suwardi, 2011)

Chow test atau menggunakan $\mathrm{F}$ restricted, dimana uji ini berfungsi untuk menentukan apakah model yang akan dipilih adalah model pooled Least Square atau model Fixed Effects . Dengan hipotesis sebagai berikut:

H0 : model pooled Least Square

H1 : model Fixed Effects

Tolak H0 jika nilai dari chow test statistik (F-statistik) lebih besar dari $\mathrm{F}$ table, atau nilai $\mathrm{F}<$ alfa. Jika H0 ditolak, maka model yang akan digunakan dalam uji formal adalah model Fixed Effects. Namun jika nilai nilai F > alfa maka model yang akan digunakan adalah model pooled Least Square.

Hausman Test berfungsi untuk menentukan apakah model yang akan dipilih adalah model Random Effectatau model Fixed Effects. Hipotesis yang digunakan dalam uji ini adalah sebagai berikut:

H0 : model Random Effect

$\mathrm{H} 1$ : model Fixed Effects

Dimana H0 akan ditolak jika nilai Prob $\mathrm{F}<$ alfa, sehingga model yang dipilih adalah Fixed Effects. Dan apabila nilai Prob F > alfa maka tolak H1 sehingga model yang dipilih adalah model Random Effect.

Lagrange Multiplier Test digunakan untuk memilih model mana yang akan digunakan apakah Pooled Least Square atau Random Effect. Dengan hipotesis sebagai berikut:

$\mathrm{H} 0$ : model pooled Least Square $\mathrm{H} 1$ : model Random Effect

Tolak H0 jika Prob F < alfa, jadi model yang akan dipilih adalah model Random Effect. Dan jika Prob F > alfa model yang akan dipilih adalah model pooled Least Square.

Suwardi (2011) mengungkapkan bahwa untuk melihat permasalahan BLUE di dalam model panel perlu dilakukan pengujian asumsi klasik sebagai berikut:

Uji stasioneritas, dilakukan untuk menguji apakah data penelitian bersifat stasioner atau tidak. Suatu deret pengamatan dapat dikatakan stasioner jika prosesnya tidak 
berubah seiring dengan adanya perubahan pada deret waktu. Apabila suatu deret waktu stasioner, maka nilai tengah (mean), varians dan covariansnya tidak dipengaruhi oleh perubahan waktu pengamatan.

Uji multikolinearitas, dilakukan untuk menguji suatu model regresi yang telah terbentuk, apakah model tersebut memiliki atau terdapat korelasi yang tinggi bahkan sempurna diantara variabel-variabel yang akan diuji. Uji ini dilakukan karena model regresi yang baik seharusnya tidak terjadi korelasi yang tinggi antar variabel.

Uji Autokorelasi, dapat terjadi hanya pada data time series, sehingga uji autokorelasi pada data yang bukan time series baik itu cross section maupun panel data tidak perlu dilakukan karena hanya akan sia-sia semata dan tidak berarti. Dalam penelitian ini, penulis menggunakan data panel, sehingga tidak perlu dilakukan uji autokorelasi.

Uji heteroskedastisitas, dilakukan untuk mengetahui apakah terdapat ketidakseragaman varian dari residual model regresi. Uji ini dilakukan karena data yang baik adalah data yang bersifat homoskedastisitas.

\section{Hasil dan Pembahasan}

\section{Penentuan Teknik Analisis Data Panel}

Tabel 1. Hasil Chow Test

\begin{tabular}{ll}
\hline \multicolumn{1}{c}{ Chow Test } & \multicolumn{1}{c}{ Hasil } \\
\hline Nilai probabilitas F & 0.1477 \\
Keputusan & Common Effect \\
\hline
\end{tabular}

Tabel 2. Hausman Test

\begin{tabular}{ll}
\multicolumn{1}{c}{ Hausman Test } & \multicolumn{1}{c}{ Hasil } \\
\hline Nilai probabilitas & 0.8710 \\
Keputusan & Random effect \\
\hline
\end{tabular}

Tabel 3. Uji LM

\begin{tabular}{ll}
\hline \multicolumn{1}{c}{ LM Test } & \multicolumn{1}{c}{ Hasil } \\
\hline $\begin{array}{l}\text { Nilai LM } \\
\text { Kitung }\end{array}$ & 0.5144 \\
Keputusan & Random effect \\
\hline
\end{tabular}

Berdasarkan uji Hausman dan uji LM tersebut, maka pendekatan yang digunakan untuk melakukan estimasi adalah model random effect.

Tabel 4. Uji Stasioneritas

\begin{tabular}{lcc}
\hline \multicolumn{1}{c}{ method } & Statistic & Prob.** $^{* *}$ \\
\hline ADF - Fisher & 193.445 & 0.0000 \\
Chi-square & & \\
ADF - Choi & -11.9598 & 0.0000 \\
Z-stat & & \\
\hline
\end{tabular}

Berdasarkan tabel 4. hasil uji stasioneritas dapat disimpulkan bahwa data bersifat stasioner (konstan).

Tabel 5. Uji Multikolinearitas

\begin{tabular}{ccccc}
\hline & $\Delta \mathbf{C A}$ & $\mathbf{I}_{\text {it-1 }}$ & $\Delta \mathbf{A}$ & $\mathbf{C A}_{\text {it-1 }}$ \\
\hline$\Delta \mathrm{CA}$ & 1.000000 & -0.00989 & -0.163876 & -0.030801 \\
$\mathrm{I}_{\text {it-1 }}$ & -0.00989 & 1.000000 & -0.10754 & 0.098261 \\
\hline
\end{tabular}

\begin{tabular}{ccccc}
\hline$\Delta \mathrm{A}$ & -0.163876 & -0.10754 & 1.000000 & 0.012516 \\
$\mathrm{CA}_{\mathrm{it}-1}$ & -0.030801 & 0.098261 & 0.012516 & 1.000000 \\
\hline
\end{tabular}

Dari tabel 5. hasil uji multikolinearitas tersebut dapat dilihat bahwa pada data penelitian tidak terdapat masalah multikolinearitas yang serius dalam variabel, karena korelasi (r) masing-masing variabel $<0.8$.

Tabel 6. Uji Heterokedastisitas

\begin{tabular}{lll}
\hline \multicolumn{3}{c}{ Heteroskedasticity Test: Glejser } \\
\hline F-statistic & 1.935930 Prob. F(3,136) & 0.1267 \\
Obs*R-squared & 5.733752 Prob. Chi-Square(3) & 0.1253 \\
Scaled & 14.31876 Prob. Chi-Square(3) & 0.0025 \\
explained SS & & \\
\hline
\end{tabular}

Pada tabel 6. hasil uji heterokedastisitas dapat disimpulkan bahwa terima $\mathrm{H} 0$ atau tidak ada gejala heteroskedastisitas yang terjadi, karena $0.1253>0.05$.

\section{Uji Global (F stat)}

Tabel 7. Hasil regresi dengan model random effect

\begin{tabular}{ll}
\hline R-squared & $\mathbf{0 . 0 3 0 8 7 3}$ \\
\hline
\end{tabular}

Pada tabel 7. Hasil regresi dengan model random effect dapat dilihat bahwa nilai probabilitas (F-statistic) > alfa, yaitu $0.232727>0.05$. Sehingga dapat disimpulkan bahwa seluruh variabel independen memiliki pengaruh yang tidak signifikan terhadap variabel dependen.

\section{Uji T (Uji Parsial)}

Tabel 8. Uji parsial

\begin{tabular}{|c|c|c|}
\hline$\Delta \mathbf{C A}$ & Coefficient & Prob. \\
\hline $\mathrm{C}$ & $1.58 \mathrm{E}+10$ & 0.3074 \\
\hline Iit-1 & -0.038327 & 0.6655 \\
\hline$\Delta \mathrm{A}$ & $-3.39 \mathrm{E}+09$ & 0.0471 \\
\hline $\mathrm{CA}_{\mathrm{it}-1}$ & -0.254917 & 0.7024 \\
\hline
\end{tabular}

Berdasarkan tabel 8. Uji parsial yang diperoleh dari estimasi model random effect, menunjukkan bahwa konstanta variabel dependen perubahan absolut transaksi berjalan $(\triangle \mathrm{CA})$ adalah $1.58 \mathrm{E}+10$, apabila nilai dari variabel-variabel independen nol.

Variabel independen Investasi pada tahun sebelumnya, yang ditetapkan dari jumlah gross fix capital formastion dan change in stock (inventories) memiliki pengaruh negatif terhadap perubahan absolut transaksi berjalan tetapi tidak signifikan, dimana tingkat probabilitas $0.6655>0.05$ (tingkat kepercayaan $95 \%$ yang telah ditentukan). Sehingga apabila terjadi peningkatan sebesar satu persen terhadap investasi dengan asumsi bahwa variabel-variabel independen lain tetap, maka akan menurunkan tingkat perubahan absolut transaksi berjalan sebesar $0.038327 \%$.

Variabel independen produktivitas berpengaruh negatif dan signifikan terhadap transaksi berjalan, dengan tingkat probabilitas $0.0471<0.05$. Sehingga apabila terjadi satu persen peningkatan pada perubahan absolut produktivitas akan berdampak negatif secara signifikan dan menurunkan tingkat perubahan absolut transaksi berjalan sebesar $3.39 \mathrm{E}+09 \%$. Dengan asumsi bahwa variabel-variabel independen lain adalah tetap.

Variabel independen $\mathrm{CA}_{\mathrm{it}-1}$ atau transaksi berjalan pada tahun sebelumnya menunjukkan bahwa nilai probabilitas variabel 
tersebut adalah $0.7024>0,05$ sehingga $\mathrm{CA}_{\text {it- } 1}$ memiliki pengaruh negatif terhadap perubahan absolut transaksi berjalan tetapi tidak signifikan. Dimana jika terjadi peningkatan sebesar satu persen terhadap transaksi berjalan pada tahun sebelumnya dengan asumsi bahwa variabelvariabel lainnya tetap akan menurunkan tingkat perubahan absolut transaksi berjalan sebesar $-0.254917 \%$.

\section{Interpretasi Hasil}

\section{Pengaruh Produktivitas terhadap transaksi berjalan}

Hasil estimasi model random effect menunjukkan bahwa hubungan antara produktivitas terhadap transaksi berjalan adalah negatif dan signifikan. Dimana peningkatan pada produktivitas akan berpengaruh negatif terhadap transaksi berjalan dengan korelasi yang meyakinkan. Berdasarkan data negara ASEAN yaitu Cambodia, Indonesia, Malaysia, Philippines, Singapore, Thailand, dan Vietnam pada gambar 1. Juga menunjukkan hal yang sama, yaitu tingkat produktivitas memang menunjukkan pengaruh yang negatif terhadap transaksi berjalan.

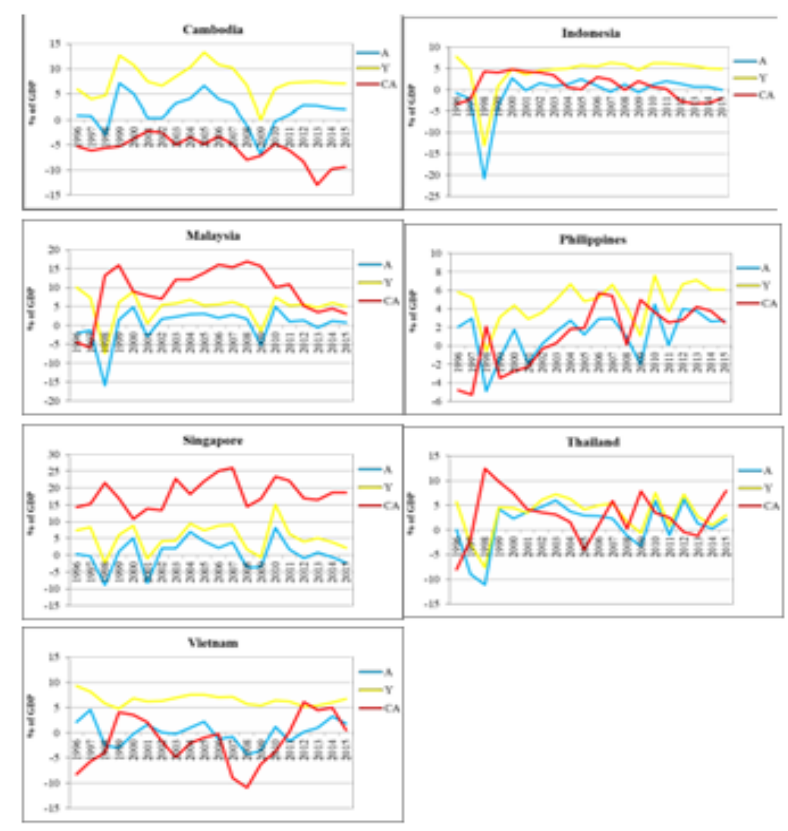

Grafik 3. Pengaruh Produktivitas Terhadap Transaksi Berjalan

Pada grafik 3 tersebut dapat dilihat bahwa produktivitas menunjukkan pengaruh yang negatif terhadap transaksi berjalan. Hal ini disebabkan karena produktivitas negara ASEAN dari tahun 1996-2015 mempengaruhi transaksi berjalan secara tidak langsung melalui pertumbuhan ekonomi. Dimana tingkat produktivitas berjalan beriringan dengan pertumbuhan ekonomi di setiap negara, jika produktivitas meningkat pertumbuhan ekonomi juga meningkat sementara semakin tinggi pertumbuhan ekonomi semakin tinggi pula tingkat defisit pada transaksi berjalan, dengan kata lain tingkat pertumbuhan ekonomi saling bertolak belakang dengan transaksi berjalan. Fakta tersebut membenarkan Roubini (1997) dan Lebe (2008) yang mengatakan bahwa ketika produktivitas suatu negara stabil dan bahkan meningkat akan berdampak pada pertumbuhan ekonomi yang semakin tinggi, sementara pertumbuhan ekonomi merupakan salah satu faktor yang paling penting atas defisit transaksi berjalan.
Berdasarkan teori, produktivitas memang dianggap mampu meningkatkan tingkat produksi yang kemudian diikuti dengan peningkatan ekspor, namun yang terjadi di negara ASEAN terutama beberapa negara berkembang seperti Cambodia, Indonesia dan Philippines, tingkat konsumsi negara tersebut lebih besar dibandingkan dengan tingkat ekspor per tahunnya seperti yang terlihat pada gambar 2 . Grafik perbandingan tingkat konsumsi dan ekspor sebagai berikut:

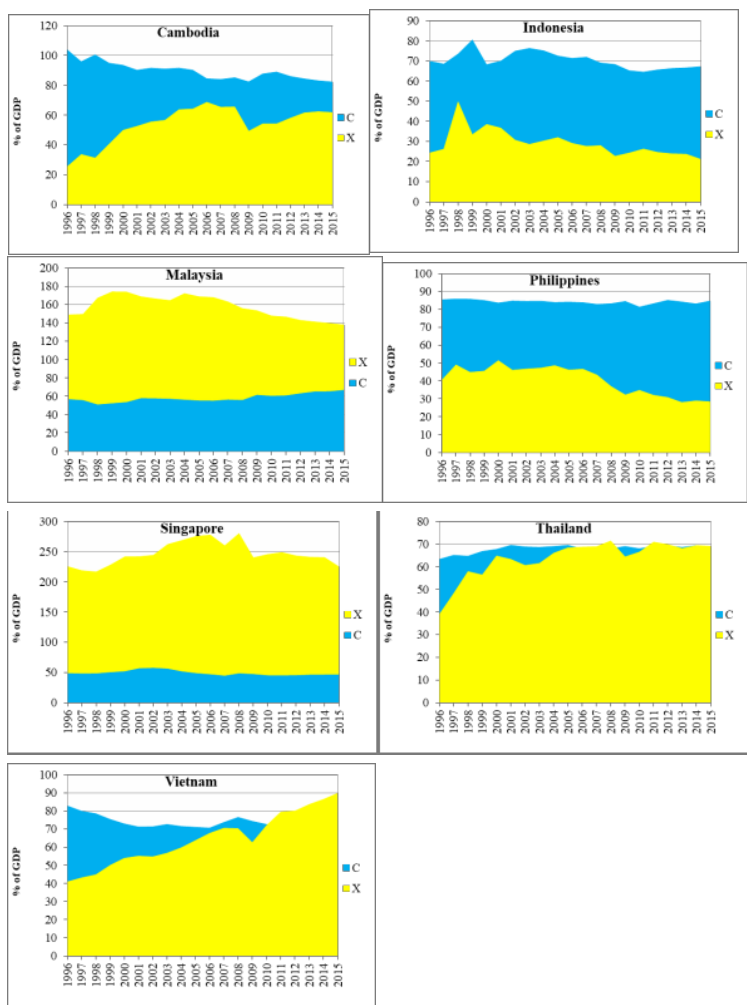

Grafik 4. Perbandingan Tingkat Konsumsi Dan Ekspor

Tingkat konsumsi yang lebih besar dibandingkan ekspor karena Intensitas pertumbuhan ekonomi yang semakin meningkat akibat tingginya produktivitas inilah yang mengakibatkan tidak terjadi perubahan pada keseimbangan transaksi berjalan negara tersebut bahkan cenderung ke arah negatif (defisit transaksi berjalan).

\section{Pengaruh investasi terhadap transaksi berjalan}

Berdasarkan hasil estimasi model random effect hubungan antara Investasi terhadap transaksi berjalan adalah negatif meskipun tidak signifikan (korelasinya kurang meyakinkan). Hal ini disebabkan karena tingkat investasi negara ASEAN sejak tahun 1996-2015 rata-rata tidak lebih besar dibandingkan dengan tingkat saving (tabungan) seperti yang telah diperlihatkan pada gambar 3. grafik pengaruh investasi terhadap transaksi berjalan, Terra $(2015: 10)$ bahwa defisit transaksi berjalan terjadi jika investasi suatu negara lebih besar dibandingkan dengan tabungan negara tersebut.

Pada grafik 3 tersebut dapat dilihat bahwa produktivitas menunjukkan pengaruh yang negatif terhadap transaksi berjalan. Hal ini disebabkan karena produktivitas negara ASEAN dari tahun 1996-2015 mempengaruhi transaksi berjalan secara tidak langsung melalui pertumbuhan ekonomi. Dimana tingkat produktivitas berjalan beriringan 
dengan pertumbuhan ekonomi di setiap negara, jika produktivitas meningkat pertumbuhan ekonomi juga meningkat sementara semakin tinggi pertumbuhan ekonomi semakin tinggi pula tingkat defisit pada transaksi berjalan, dengan kata lain tingkat pertumbuhan ekonomi saling bertolak belakang dengan transaksi berjalan. Fakta tersebut membenarkan Roubini (1997) dan Lebe (2008) yang mengatakan bahwa ketika produktivitas suatu negara stabil dan bahkan meningkat akan berdampak pada pertumbuhan ekonomi yang semakin tinggi, sementara pertumbuhan ekonomi merupakan salah satu faktor yang paling penting atas defisit transaksi berjalan.

Berdasarkan teori, produktivitas memang dianggap mampu meningkatkan tingkat produksi yang kemudian diikuti dengan peningkatan ekspor, namun yang terjadi di negara ASEAN terutama beberapa negara berkembang seperti Cambodia, Indonesia dan Philippines, tingkat konsumsi negara tersebut lebih besar dibandingkan dengan tingkat ekspor per tahunnya seperti yang terlihat pada gambar 2 Grafik perbandingan tingkat konsumsi dan ekspor sebagai berikut:

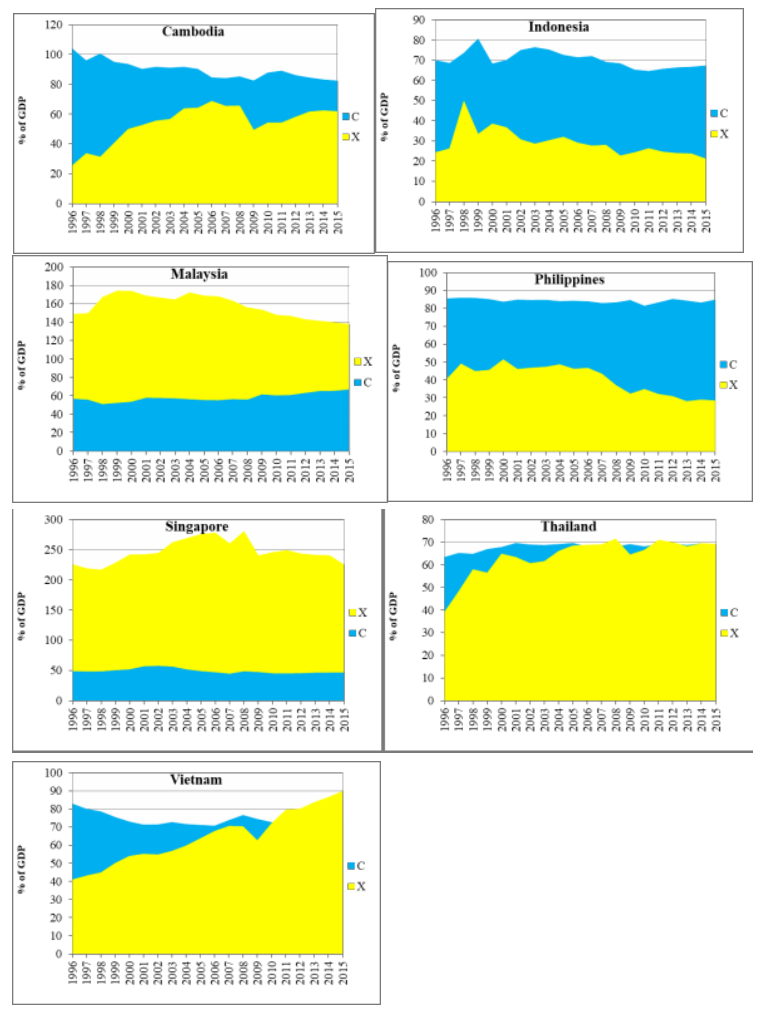

Grafik 4. Perbandingan Tingkat Konsumsi Dan Ekspor

Tingkat konsumsi yang lebih besar dibandingkan ekspor karena Intensitas pertumbuhan ekonomi yang semakin meningkat akibat tingginya produktivitas inilah yang mengakibatkan tidak terjadi perubahan pada keseimbangan transaksi berjalan negara tersebut bahkan cenderung ke arah negatif (defisit transaksi berjalan).

\section{Pengaruh investasi terhadap transaksi berjalan}

Berdasarkan hasil estimasi model random effect hubungan antara Investasi terhadap transaksi berjalan adalah negatif meskipun tidak signifikan (korelasinya kurang meyakinkan). Hal ini disebabkan karena tingkat investasi negara ASEAN sejak tahun 1996-2015 rata-rata tidak lebih besar dibandingkan dengan tingkat saving (tabungan) seperti yang telah diperlihatkan pada gambar 3. grafik pengaruh investasi terhadap transaksi berjalan, Terra $(2015: 10)$ bahwa defisit transaksi berjalan terjadi jika investasi suatu negara lebih besar dibandingkan dengan tabungan negara tersebut.

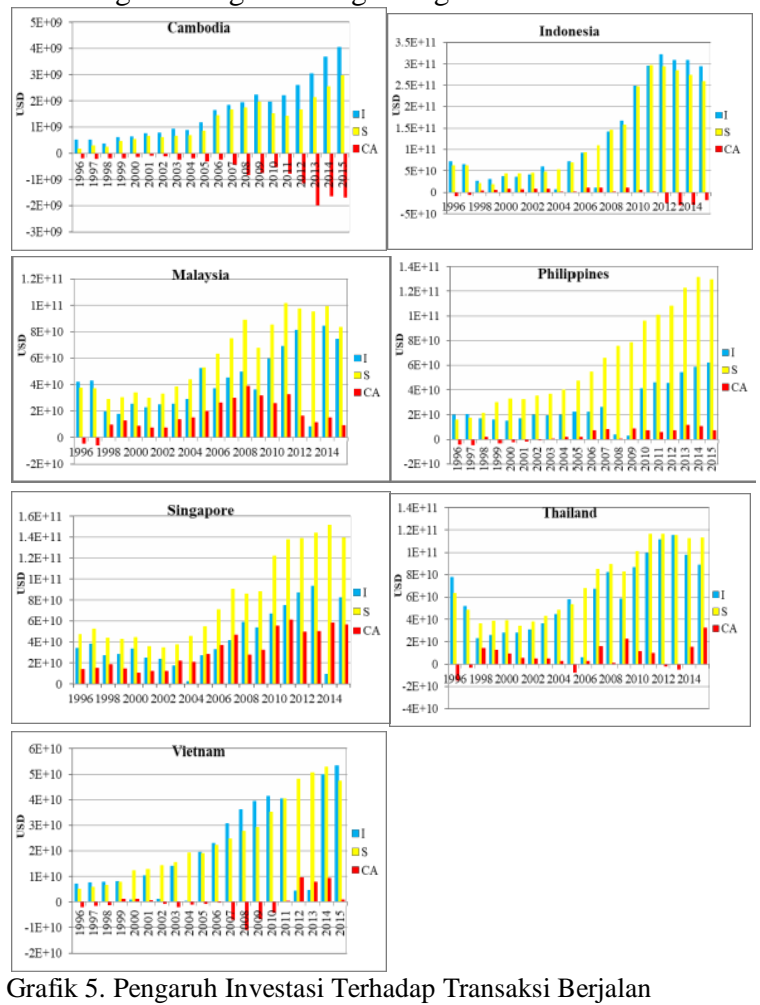

Pada Grafik 5. pengaruh investasi terhadap transaksi berjalan dapat dilihat bahwa tingkat Investasi negara ASEAN sejak tahun 1996-2015 rata-rata tidak lebih besar dibandingkan dengan tingkat tabungan negara tersebut. Negara yang tingkat investasinya lebih besar dibandingkan dengan tabungan sejak tahun 1996-2015 secara berkesinambungan hanyalah Cambodia.

Hal tersebut disebabkan karena Cambodia adalah salah satu negara berkembang yang perekonomiannya paling terbuka. Perekonomian Cambodia didominasi oleh pertanian (agryculture) dengan beras sebagai hasil panen utama. Sejak negara tersebut menyusun ulang konstitusional monarki pada tahun 1993, pertumbuhan ekonomi negara tersebut berkembang sangat pesat, kecuali pada periode sekitar pertengahan 1997 dan akhir tahun 1998 ketika terjadinya ketidakstabilan politik yang disebabkan oleh krisis keuangan Asia. Cambodia mulai melambung kembali pada akhir tahun 1998 dengan adanya penyusunan koalisi pemerintahan, tetapi investasi asing di Cambodia pada hampir semua sektor melambat bahkan ketinggalan. Kemudian sejak awal tahun 1999, pemerintah membentuk kembali program intensif perekonomiannya, institusi keuangan internasional ikut berpartisipasi dalam proses tersebut dan menyumbangkan bahkan memonitor. Sejak saat itu keseluruhan prioritas pembangunan dari pemerintahan Kerajaan Cambodia (The Royal Government of Cambodia) yang disebut dengan Strategi Segitiga Pembangunan (Development Triangle 
Strategy) yaitu membangun kedamaian dan stabilitas, integrasi ekonomi dan reduksi kemiskinan diwujudkan dengan cara meningkatkan percepatan perumbuhan ekonomi, stabilitasi, dan membangun fondasi yang kuat untuk pembangunan yang berkesinambungan melalui intensitas investasi (United Nations, 2003).

\section{Kesimpulan}

Berdasarkan pembahasan pada bab sebelumnya mengenai pengaruh produktivitas dan investasi terhadap transaksi berjalan di negara ASEAN tahun 1996-2015 menggunakan analisis regresi data panel dengan model random effect dapat disumpulkan bahwa:

Produktivitas berpengaruh negatif dan signifikan terhadap transaksi berjalan di negara ASEAN tahun 1996-2015, dengan tingkat probabilitas $0.0471<0.05$. Sehingga apabila terjadi satu persen peningkatan pada perubahan absolut produktivitas akan berdampak negatif secara signifikan dan menurunkan tingkat perubahan absolut transaksi berjalan sebesar -3.39E+09 \%. Dengan asumsi bahwa variabelvariabel independen lain adalah tetap. Hal ini disebabkan karena produktivitas negara ASEAN dari tahun 1996-2015 mempengaruhi transaksi berjalan secara tidak langsung melalui pertumbuhan ekonomi.

Investasi yang ditetapkan dari jumlah gross fix capital formastion dan change in stock (inventories) memiliki pengaruh yang negatif terhadap perubahan transaksi berjalan tetapi tidak signifikan, dimana tingkat probabilitas $0.6655>0.05$ (tingkat kepercayaan $95 \%$ yang telah ditentukan). Hal ini disebabkan karena tingkat investasi negara ASEAN sejak tahun 1996-2015 tidak lebih besar dibandingkan dengan tingkat saving (tabungan) dari masingmasing negara. Negara yang tingkat investasinya lebih besar dibandingkan dengan tabungan sejak tahun 1996-2015 secara berkesinambungan hanyalah Cambodia.

Asian Productivity Organization (APO) http://www.apotokyo.org/. Diambil pada 11 April, 2018.

Glick, Reuven and Kenneth Rogoff (1995). Global versus Country-Specific Productivity Shocks and the Current Account, Journal of Monetary Economics, 35, 159-192.

Gracia, F. P. \& Cunano, J. (2001). Intertemporal current account and productivity shocks: evidence for some European countries. Asociación Española de Documentos de economía y Finanzas Internacionales.

Gujarati, Damodar N. (2004). Basic Econometrics. Fourth edition.The McGraw-Hill Companies. New York.

Gujarati, D. N., \& Porter, D. C. (2010). Dasar-dasar
Ekonometrika. Jakarta: Salemba Empat.

International Financial Statistics (IFS), International Monetary Fund (IMF). $\underline{\text { http://www.imf.org/external/index.ht } \mathrm{m} \text {. Diambil pada }}$ 14 Mei, 2018.

Khadaroo, A.J. \& Ramlall, I. 2012. Sustainability of current account deficit in Mauritius : Towards a reversal?. Department of Economics and Statistics, University of Mauritius.

Lebe, F., Kayhan, S., Adiguzel, U., \& Yigit, B. (2008). The empirical Analysis of

The Effects od Economic Growth and Exchange Rate on Current Account Deficit: Romania and Turkey samples. Journal of Applied Quantitative Methods.

Lieberman, M. B., \& Kang, J. (2008). How to measure company productivity using value-addded: A focus on pohan steel (POSCO). Asia pacific journal of management 25(2), 209-

224.

Newman, Carol; Rand, John; Tarp, Finn, \& Nguyen. (2014). Exporting and Productivity: The role of ownership and innovation in the case of Vietnam, WIDER working paper, No. 2014/070, WIDER, Helsinki.

Roubini, N. \& Wachtel, P. (1997). Current Account Sustainability in Transition Economics. NBER Working Paper. No.6468.

Sugiartiningsih.(2013). Pengaruh produktivitas kerja Indonesia dan apresiasi dolar Amerika Serikat terhadap ekspor Indonesia ke Amerika Serikat periose 1988-2012. Universitas Widayatama.

Suwardi, Akbar . (2011). Stata : Tahapan dan Perintah (Syntax) Data Panel. Laboratorium Komputasi Departemen Ilmu Ekonomi Fakultas Ekonomi Universitas Indonesia

Terra, Cristina. (2015). Principles Of International Finance And Open Economy Macroeconomics. Elsevier Inc.

The United Nations. (2003). An Investment Guide to Cambodia. The UNCTAD- ICC Series of Investment Guides.

Valderrama, D. (2007). The U.S. Productivity Acceleration and the Current Account Deficit. Economic research Federal Reserve Bank of San Francisco. 